\title{
Evaluation of Teacher Performance in Teaching and Learning Process
}

\author{
Ratna Khairunnisa ${ }^{1}$, Nurul Hikmah' ${ }^{2}$, Juan Vicki Ada'Komman ${ }^{3}$ \\ \{ratna@uwgm.ac.id ${ }^{1}$,nhikmah923@yahoo.com² ${ }^{2}$ juanvicky7@gmail.com ${ }^{3}$ \} \\ ${ }^{1,2,3}$ University of Widya Gama Mahakam, Jl. K. H. Wahid Hasyim No. 28 Samarinda, East Borneo
}

\begin{abstract}
This study aims to evaluate teacher performance in teaching and learning process at SDN 014 Pa'Padi sub-district of Krayan. The researchers applied qualitative approach to collect and analyze data from four participants, consisting of a headmaster and three teachers of SDN $014 \mathrm{~Pa}$ 'Padi sub-district of Krayan, as the research subjects. In collecting the data, the researchers conducted interview, field notes (observation), and documentation. The data were analyzed through data reduction, data display, and drawing conclusion by using CIPP (context, input, process, and product) method. Observation result showed that performance of civil servant teacher was in very good criteria, making up $61,11 \%$. Meanwhile, performance of non-permanent teachers is in good criteria, making up $83,33 \%$. In brief, performance of non-permanent teacher was better than civil servant teacher due to their 'unsafe' status and career in teaching. When their performance does not meet standard, government might stop their career in teaching.
\end{abstract}

Keywords: Evaluation, teacher performance, teaching and learning process

\section{Introduction}

Teacher is the main component that mostly determines the success of education. Therefore, it is a must for teacher to have academic qualification, professional teacher certificate, physically and mentally healthy, and capability to achieve national education target, followed by teacher's main responsibility, specifically; to educate, to teach, to guide, to lead, to train, to assess and to evaluate students in formal education at level of early childhood education, primary education and secondary education[1]. It is important to develop teacher's competence continuously to produce qualified and professional teacher. As a main resource at school, teacher is required to be innovative and creative in learning process as well as in self-development for her/his competence[2]. Teachers, especially those who are civil servant, are obliged to enhance their competence through trainings and workshops, classroom action research, making scientific research, and scientific innovation, that will facilitate teachers for promotion and becoming professional teachers[3].

Teacher performance is the manifestation of their main responsibility as teacher. The better they perform their responsibility, the more visible their qualified performance [4]. It prevails to both types of teacher; civil servant teachers and non-permanent teachers. Teachers' service is expected to shape better generation who are ready to inherit good culture as well as to fight for it[5].

As civil servant teachers, they receive not only basic salary, but also some allowances, such as functional allowance, wife allowance, rice allowance and child support[6]. Despite those 
allowances, government also gives them incentives. For the non-permanent teachers, those who meet the requirements are assigned by authorized official to accomplish state duty and paid based on applicable rules and regulations[7]. In addition, other permanent teachers are assigned by government with agreement employment or so called PPPK Teachers. These teachers receive welfare guarantee from government at central, provincial, level II region and committees. Government gives them chances to develop their career, such as by giving them opportunity to take test for applying civil servant position, and will be assigned as civil servant when they meet the particular requirement, such as having amazing achievement or having served for long time at school[8]. It is clearly seen that government has given better welfare to the civil servant teacher than the PPPK teachers. However, both types of teachers have same responsibility and roles in educating. They also have the same main and additional duty. In other words, they have the same duty and responsibility as teachers.

There are ten teachers inSDN 014 Pa'Padi at Krayan sub-district in Nunukan Regency North Borneo, consisting of four civil servant teachers and six PPPK teachers. Related to the issue above, it can be said that the civil servant teachers are more prosperous compared with the PPPK teachers but still have the same responsibility and roles as teacher. However, based on preliminary observation, the researchers found some weaknesses on teacher performance, especially for civil servant teachers [9]. It is found that the civil servant teachers have weaknesses in planning lesson, implementing the lesson, evaluation the learning result, guiding and training students, and carrying out additional tasks[10]. The weak performance of civil servant teachers does not meet government expectation by giving guarantee on their prosperity.

Some civil servant and PPPK teachers refer to their lesson plans during teaching. Yet, from indicator of activeness, the PPPK teachers are more active to guide students in extracurricular activities, spiritual activities and self-development, compared with the civil servant teachers. In terms of preparing teaching device and administration, the civil servant teachers prepare them only when they are being supervised at school[11]. The same condition did not happen to the PPPK teachers. In general, the civil servant teachers are not quite assertive in handling students who broke school rules. Based on the explanation above, the researcher was interested in conducting research on "Evaluation on Teacher Performance in Teaching and Learning Process in SDN 014 Pa'Padi in Krayan Sub-district"

\section{Method}

Research subjects are those are appointed to be researched by the researcher. In qualitative research, it is essential to carefully choose the subject. There is no population for this type of research. The researcher applied purposive sampling to select the subject based on the needed criteria[12].

1. Headmaster of SDN 014 Pa'Padi Krayan Sub-district

2. Three teachers of SDN 014 Pa'Padi Krayan sub-district. (1 civil servant teachers dan 2 nonpermanent teachers)

Primary data source is data source that comes directly from the informant or subject through interview, observation and documentation. In this study, the researcher used the informant as the primary source. Secondary data source is supporting data source for the primary data such as from literatures and documentation and other supporting data. In this study, the secondary data were data from civil servant and non-permanent teachers. 
The data were analyzed since before the researcher came to the research setting to determine research focus. Data analysis in qualitative research was done during data collection, after data collection on particular period. Even though during interview, the answers must be analyzed soon. According to Sugiyono (2013), qualitative data are analyzed interactively and simultaneously until the data are saturated. The steps of data analysis involve data reduction, data display and conclusion/verification.

\section{Result and Discussion}

Teacher performance in teaching and learning process is defined as teacher capability to create educative communicative atmosphere among teachers and students, involving cognitive, affective and psychomotor aspects as an effort to learn something based on planning, evaluation and follow-up action to reach teaching objectives. The pedagogical competence relates to teacher capability in teaching and learning process, concerning with the teaching preparation; lesson planning, implementation of teaching scenario, choosing teaching method and media of teaching, as well as evaluation tool to reach education objectives that cover student's cognitive, affective and psychomotor aspects.

Teacher Performance in Lesson Planning

Both civil servant teachers and non-permanent teachers are required to make lesson plans as learning material which will be explained in the classroom. However, the civil servant teachers make the lesson plan for all learning material once a week, meanwhile, non-permanent teachers make the lesson plan every day which is considered not efficient enough since their time is mostly used for making lesson plans rather than teaching.

Teacher Performance in Learning Activity

During the learning activity, the teachers conducted post-test, learning activities and evaluation after each learning unit learnt by students. This result confirms Sanjaya's (2012:31) theory, stating that, having making lesson plans, teacher must apply the lesson plan during the learning activity, and provide educative interaction among students and teacher during the learning process.

Teacher Performance in Learning Evaluation

The civil servant teachers and the non-permanent teachers have given score and evaluation objectively to students based on students' capability in receiving lesson from the teachers. Regarding to the score report, only the civil servant teachers make the report to be given to students' parents. Meanwhile, the non-permanent teachers give evaluation monthly or in three months to students' parents so that they know their child's development at school in teaching and learning process.

Teacher Performance in Discipline Matter

Both civil servant and non-permanent teachers obey rules and regulation applied at school. However, the civil servant teachers use their time ineffectively. They prefer to use their time for chatting with other teachers. On the other side, the non-permanent teachers use their time effectively by preparing learning material. Wardani (2017) confirms that discipline matter is one of indicator to assess teacher performance, including finishing making lesson plan on time and being punctual in teaching. In completing tasks given by school principal, the civil servant teachers tend to be slower compared with the non-permanent teachers since they managed to accomplish the task on time making their performance better. 
Based on observation result in SDN 014 at Krayan sub-district, the performance of the civil servant teachers was $61.11 \%$ categorized good; meanwhile the non-permanent teachers make $83.33 \%$ categorized very good. The following figure will show the result;

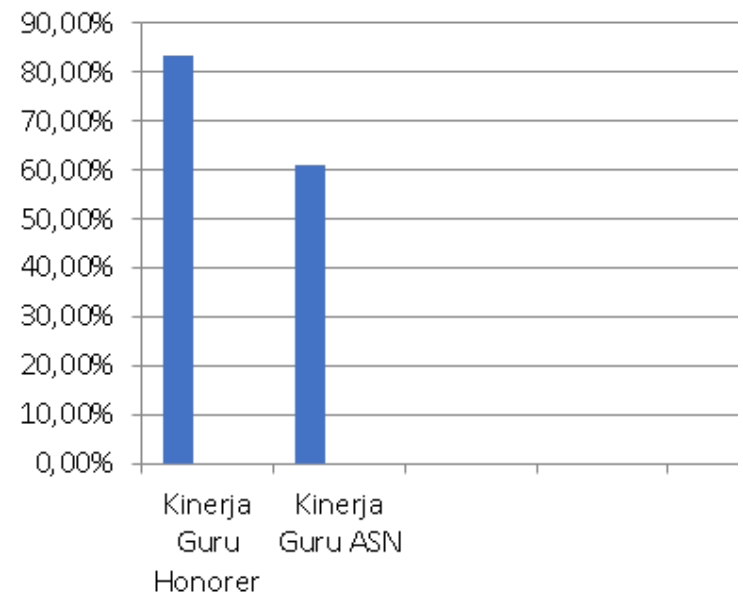

Figure 1

Teaching Evaluation/Reflection

To evaluate the teaching result and measure students' understanding on lesson given, the non-permanent teachers often make evaluation report for students. On the other hand, the civil servant teachers seldom do the report. Whether the lesson has been mastered by students or not, the non-permanent teachers keep making the evaluation report as their reflection during teaching and give learning material to students. Meanwhile, the civil servant teachers make the report only after exam at the end of semester. In conclusion, the performance of non-permanent teachers is better than the civil servant teacher performance due to their career sustainability and employment status. They worry that when they perform badly, government will take back their right as non-permanent teacher.

\section{Conclusion}

The performance of non-permanent teachers is considered better than the civil servant teacher performance. The non-permanent teachers need to sustain their employment status and teaching career by performing well.

\section{References}

[1] B. Bruns, L. Costa, and N. Cunha, "Through the looking glass: Can classroom observation and coaching improve teacher performance in Brazil?," Econ. Educ. Rev., vol. 64, pp. 214 $250,2018$. 
[2] A. Suknaisith, S. Wongwanich, and C. Piromsombat, "Development of Teacher Performance in Educational Measurements and Evaluation through Self-monitoring Strategies," Procedia - Soc. Behav. Sci., vol. 116, pp. 1683-1688, 2014.

[3] L. Woessmann, "Cross-country evidence on teacher performance pay," Econ. Educ. Rev., vol. 30, no. 3, pp. 404-418, 2011.

[4] G. Kelemen, "Performer, a Way to Promote Performance in Teachers Training," Procedia - Soc. Behav. Sci., vol. 191, pp. 1745-1749, 2015.

[5] B. Naoreen, H. Gull, F. Asghar, and A. Mahmood, "Gender Wise Comparison of Trained and Untrained Teachers' Performance on Students' Learning Achievement in Mathematics," Procedia - Soc. Behav. Sci., vol. 116, pp. 3016-3020, 2014.

[6] P. Thongnin, S. Wongwanich, and C. Piromsombat, "Multi-task Integration as a Strategy for Improving Teacher Performance and Student Learning," Procedia - Soc. Behav. Sci., vol. 116, pp. 1919-1924, 2014.

[7] C. Bradford and M. Braaten, "Teacher evaluation and the demoralization of teachers," Teach. Teach. Educ., vol. 75, pp. 49-59, 2018.

[8] M. W. Rodrigues, S. Isotani, and L. E. Zárate, "Educational Data Mining: A review of evaluation process in the e-learning," Telemat. Informatics, vol. 35, no. 6, pp. 1701-1717, 2018.

[9] B. A. Jacob, J. E. Rockoff, E. S. Taylor, B. Lindy, and R. Rosen, "Teacher applicant hiring and teacher performance: Evidence from DC public schools," J. Public Econ., vol. 166, pp. 81-97, 2018.

[10] F. Barrera-Osorio and D. Raju, "Teacher performance pay: Experimental evidence from Pakistan," J. Public Econ., vol. 148, pp. 75-91, 2017.

[11] B. Stacy, C. Guarino, and J. Wooldridge, "Does the precision and stability of value-added estimates of teacher performance depend on the types of students they serve?," Econ. Educ. Rev., vol. 64, pp. 50-74, 2018.

[12] Lexy J. Moelong, Metode Penelitian Kualitatif. Bandung: Bumi Aksara, 2011. 